\title{
Pages in History
}

\section{Welcome by the Editor-in-Chief}

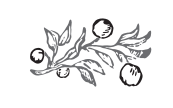

Journal of Economic Literature (JEL) codes: B20, N01

Keywords: economic policy, social policy, Hungary

A multitude of leaders and intellectuals go - overtly or covertly - after their dream to become part of history. The well-intentioned probably hope that the goods, systems, works, scientific achievements will increase to a scale people remember and benefit from after years, decades or centuries. Excellence, their excellence will be recalled in books posterity will thumb through with pleasure; they will be the stepping stones for progress and may become bases of reference. No less important is the work done by people who put their hand to a plow or stand beside a turning-lathe or work three shifts day by day focusing their energies on providing for their families and raising their children. True, we love spectacular things. Perhaps everyone loves them. But it is the daily struggle that organizes millions of families into a society and ensures sustainability. Values, traditions, love and the mother tongue can only be handed down, maintained and carried on if the smallest unit of society, the family exists.

In our performance-driven world, everyday feats go unrecognized. We have been Westernized also in this respect. However, several years ago the Hungarian government realized that at the current rate of decrease in the population, in love and tradition, and if Hungarian continue to assimilate faster than desired, the history of Hungary will come to an end. Based on more predictable economic performances, which are also more favourable than those achieved in the previous decades, government funds were used to create a large margin for family tax benefits and support for families and home projects, and thus for reducing the financial burdens of raising children. Although financial and budgetary means alone are insufficient to inspire couples to start a family. It is up to families to build focus on the family and on children in their daily life and to pass down values to the children they raise that may serve the extension of small communities (the family) instead of the ego, and fulfillment in intellectual needs and love. Although it is true that standing the ground, sometimes senselessly, against gunfire, sports achievements, intellectual creations, collective acquisition of assets, the establishment of "impact resistant" empires deserve mentioning in history books, we Hungarians are now challenged by the fact that without a major demographic change the recipients and readers of our 


\section{Pages in History - Welcome by the Editor-in-Chief}

outstanding achievements, and the hosts of potential reenactors of traditions may reduce in the future.

In numerous cases the unfavourable processes are caused by laziness, indolence and the inability to love. But we always have people who instead of binding up wounds pour salt over them. Of course, there are evil powers, the bad, who conquer by force and subdue others mentally and physically, and as they usually mean mischief, they do bad things humankind can hardly benefit from. Those who spark wars and use inventions and power against humans. After all, the world remains the infinite struggle between good and bad. And then we have economic eras, empires and courses that were or have been characterized by comprehensive taxonomical features and are taught at history classes. Of course, these "complexes" are also perishable, like the Western Roman Empire, the new barbarian times that followed, and then the Renaissance, the invention of the steam engine, and capitalism and the opening period of original capital raising that came along with it, and are now all things of the past. Our generation still saw the planned economy at operation, the hope given in the 1968 New Economic Mechanism, we tasted transition to a market economy, it was pretty werid, and so we left it behind. We have been experiencing and shaping, some still testing, the active state model, the everydays of an economic and social policy under a more intensive financial influence by the state and its effects reflected in companies and in the society. We, its shapers, do wonder if it is long-lasting. After decades and centuries will it be considered as momentuous as Dualism in Hungary after 1867? Will it be maintained for (at least) forty years, similarly to Dualism or the socialist planned economy? Or for a quarter of a century similarly to market transition?

The systems that develop the economy to improve financial and intellectual life in a society and to reinforce a nation's political independence and greatness are worthy of attention. Such systems included the economic and social upturn that started in 1867, after decades of absolutism that followed the crackdown of the 1848-1849 War of Independence. It was the dualist Hungarian State's noble struggle in the interest of modernization, for the building of a full-fledged capitalism under state control, similarly to the period between the two World Wars, especially the consolidation under PM Bethlen between 1921-1931, focused on peaceful reconstruction and of corse, on remedying the unjustice suffered, in a nearly complete national unity. Various political parties, business groups and social classes jointly endeavoured to rectify the impairments caused by the Treaty of Trianon. The political parties organized among workers "cancelled" strikes and demonstrations, and in contracts waived their rights in order to reinforce the operation of the government focusing its efforts at restoring the former boundaries. The planned economy and then the transition to a market economy, lots and lots of illusions regarding the (forced) import of economic and social conditions that differ from Hungary's characteristic features, traditions and social needs, all shattered. We became utterly indebted.

It remains a question and a conundrum if the course followed since 2010 will be remembered merely as a method that frayed out repeated election vitories or do the governments set up on the basis of elections repreated according to the rules of par- 
liamentary democracy lay the basis of a comprehensive economic era? In other words, will these four-year courses fit together to make an independent multitude of successful decades that differ from the previous courses in their key features and result in a Hungarian model that is developed in the economic and social sense of the word? Naturally, we cannot be certain, but we are fashioning it to this end. It is encouraging to see that in the past 150 years successful and memorable courses included those that could achieve economic and social expansion under government control among market economic conditions. Clearly, they included Hungarian Dualism, and more or less the period of consolidation under PM Bethlen, and the current period that started in 2010 also joins this series.

However, not everyone likes the currently applied method and government matters. Some say that in dollar terms the country's GDP performance is roughly the same as it was ten years ago. And they emphasize that the current worth is produced by 750,000 employees more, and thus the national economy's performance has only increased if calculated in forints, which means that our system is ineffective and will not be sustainable. Naturally, the question why if more people work more, why does not the gross domestic product rise in dollar terms too? The reason is that the regular attacks on the forint and speculation weakens the exchange rate of the national currency. And just one more critical objection to the above. Real wages have been increasing for seven years continuous, the minimum wage has doubled, welfare benefits are on the rise, but the depreciation of the forint and the unfavourable exchange rate reduces the income settled in forints by one-third. The government and the central bank are hardly to be blamed for this, as the forint is depreciated by a hundred or a thousand times stronger powers. They have more money for speculation as the Hungarian government or the National Bank of Hungary. The government's fiscal policy and the central bank heading in the same direction serve the survival of a system, as the economy is stable. Anyone who hopes to see wages and welfare benefits increase, companies to grow and additional extensions of family and home benefits is dependent on this policy and is interested in its maintenance. But naturally, one has to move on in economy management. There are huge reserves in small and medium-sized companies, however, their majority is still so small that they find it difficult to budget even minium wage increases. Development capacities are weak, but motivation to innovation is even weaker. A more intensive cohesion in this strategic area and building further strategic partnerships with international companies may provide an impetus. In the future the Finance Ministry will have to pay more attention to such intricate questions as wage bargaining between companies and employees. In a market economy controlled by the government, the state and the Finance Minister representing it, is not only supposed to coordinate negotiations on minimum wages and guaranteed wage minimums, as he is in charge of economy regulation, but also to promote cooperation between market-based companies and employees, and wage agreements beyond minimum wages. This was also the pattern during the times of the Monarchy. The industry promoting statutes (also) encouraged the establishment of trade-corporations, ${ }^{1}$ as the state intended to support industry organization and the interests of industrial employees. 


\title{
Pages in History - Welcome by the Editor-in-Chief
}

Thus the maintenance of economic performances, the inclusion of new growth factors, the promotion of small company integration by central bank instruments, increased state support to employee interests, a more organized social capitalization on the knowledge of "educated people" and improving the efficincy of research performances may be the sources of a new impetus. At the moment, sustainability and the creation of an economic era needs to focus on these challenges.

The period ahead of us will be a period of composed building. Despite speculations against the forint, we have charge for progress, as despite the confiscation of one third, increase in wage income calculated in forints still gives a positive balance, ${ }^{2}$ let alone real wages, which nearly doubled during the seven years in forint terms. The sector of public finances remains stable and economic growth is around five per cent. The mission of Polgári Szemle, as a journal of social sciences, is to further increase the methodological pluralism of the published scientific studies, despite the academic ranking by the Hungarian Academy of Sciences, which is not overrated, in order to enable the even more impartial exposure of reality and the processes that surround us. This is our endeavour in the Hungarian version of the journal meant for domestic readers, in the English version that will be published for the fourth time in 2019, and in the Chinese issue to be released for the first time this year.

It is worth reading Polgári Szemle!

\author{
Dr Csaba Lentner, university professor \\ Editor-in-chief of Polgári Szemle
}

\begin{abstract}
Notes
See for example: 1884: 17. tc., 1890: 14 . tc.

Let us also remember the "simple" fact that during the 1995 Bokros package, the 2006 Gyurcsány package and then the Bajnai package, pensions dropped by 10 to 30 per cent in forint terms, hundreds of thousands of families were deprived of family allowances and other government benefits, and moreover, the unemployment rate was 10 per cent, and Hungarian entrepeneurs went bankrupt by the tens of thousands. And if incomes fell, as we all remember, in forint terms, what a (further) tumble was caused in dollar terms in incormes by the regular and planned devaluation of the national currency (which was the foreign currency policy adopted by Lajos Bokros and György Surányi), or by the budget policy that was already "torpid" before the 2007-2008 world economic crisis? Piping times of peace?
\end{abstract}

